\title{
Analysis of the Influence of Risk Factors of Type 2 DM on Outpatients at DKT Bandar Hospital Lampung, 2020
}

Feby Esmiralda $^{1}$, Aila Karyus ${ }^{2}$, Kodrat Pramudho ${ }^{3}$

${ }^{1}$ Master of Public Health, Universitas Mitra Indonesia

${ }^{2}$ Master of Public Health, Universitas Mitra Indonesia

${ }^{3}$ Master of Public Health, Universitas Mitra Indonesia

Email: dian@umitra.ac.id

Received : March $2^{\text {nd }} 2021$

Accepted : May $4^{\text {th }} 2021$

Published : May 20 2021
ABSTRACT

$\mathrm{DM}$ is a chronic metabolic disease characterized by hyperglycemia and cause serious complications with an increasing prevalence rate. Control of risk factors that affect the incidence of $\mathrm{DM}$ is needed to prevent the emergence of DM and delay disease complications. The purpose of this study is to determine the risk factors that influence the incidence of type 2 diabetes outpatients at the DKT Bandar Lampung Hospital. This type of research is quantitative observational analytic with a case control approach. The population came from all patients undergoing outpatient treatment at the Internal Medicine Department of the DKT Hospital in Bandar Lampung with 44 case samples and 44 control samples. Data analysis used univariate analysis with percentages, bivariate analysis with Chi Square and multivariate analysis with multiple logistic regression. The results showed that there was a significant influence between the risk factors for age ( $\mathrm{p}$ value 0.017 ), hereditary history of diabetes ( $p$ value 0.03 ), physical activity ( $p$ value 0.002 ) and obesity ( $\mathrm{p}$ value 0.001 ) with the incidence of type 2 diabetes, while a history of hypertension has no effect on the incidence of type 2 diabetes mellitus ( $p$ value 0.135 ). Meanwhile, the most dominant variable influencing the incidence of outpatient type 2 diabetes mellitus at DKT Bandar Lampung Hospital is physical activity with OR 5.29. Maximum promotive, preventive, curative and rehabilitative efforts are needed to control risk factors for type 2 diabetes

Keywords: Influence, age, hereditary history, history of hypertension, physical activity, obesity, diabetes mellitus

Copyright (C) 2021 IIK STRADA Indonesia All right reserved. \section{International License.}

This is an open-acces article distributed under the terms of the Creative Commons Attribution-ShareAlike 4.0

\section{INTRODUCTION}

DM is a chronic metabolic disease characterized by blood glucose levels (hyperglycemia) exceeding normal because the pancreas cannot produce enough insulin or insulin function is reduced and can cause serious complications in the heart, blood vessels, eyes, kidneys and nervous system. DM is the leading cause of blindness, kidney failure, heart attack, stroke and amputation of the lower leg. A person suffering from diabetes is three times more likely to have a stroke and heart attack.

Based on the classification from WHO, DM is divided into several types, namely Insulin dependent diabetes mellitus / IDDM or DM Type 1, Non Independent Diabetes mellitus / NIDDM or type 2 DM, a hybrid form of DM, unclassified DM and hyperglycemia during pregnancy. $90 \%-95 \%$ of all types of DM are type $2 \mathrm{DM}$

Based on data from the International Diabetes Federation (IDF), in 2019, there are 463 million adults in the world with an age range of $20-79$ years who are diabetic. It is estimated that the 
number of sufferers will increase to 629 million people in 2045 with the possibility of an increase in sufferers of type 2 diabetes. $79 \%$ of adult DM sufferers in the world live in countries with lower middle income with the highest number of cases in the age range $40-59$ years and $66 \%$ of DM sufferers live in urban areas.From the results of the WHO survey in 2016 in Indonesia, there were $7 \%$ of DM sufferers from the total population (258 million people), approximately 18,060,000 people with the majority of patients with overweight and less physical activity and the number of deaths as many as 48,300 people in the age range 30 years - 69 years.

The results of Riskesdas in 2018 showed an increase in the incidence of DM sufferers in people aged $\geq 15$ years, namely to $8.5 \%$ (basic diagnosis of the 2011 Perkeni Consensus) compared to the 2013 Riskesdas results, which was 6.9\% (Perkeni Consensus 2011) and increasing again in the 2018 Riskesdas results using the 2015 Perkeni criteria, namely 10.9\% sufferers. In Indonesia, the highest prevalence of DM is in DKI Jakarta and the lowest is in the Province of East Nusa Tenggara with $0.6 \%$ more female sufferers than male sufferers.

Diabetes Mellitus has a negative impact on public health because of its impact on the quality of human resources and a significant increase in health costs because this disease is a chronic disease and can be carried for life. Diabetes Mellitus Type 2 can be prevented, delayed or eliminated by controlling risk factors

The Government of Indonesia through the Ministry of Health and the health office at the provincial / district / city level has implemented a prevention program for non-communicable diseases, in this case Diabetes mellitus, as an action to suppress and control the incidence of diabetes. The program focuses on health promotion, control of modifiable risk factors such as lifestyle, obesity, lack of physical activity, smoking habits, poor diet and early detection of cases.

The research location is in the DKT Bandar Lampung Hospital, which is a Level IV Hospital belonging to the Indonesian Army. Based on data from the Bandar Lampung DKT Hospital, there is an increase in data on visits of DM sufferers every year. DM management must involve various parties, both medical / paramedical personnel, people with DM and their families and the community need to continuously improve knowledge and understand about the course of the disease, prevention of complications, management and control of risk factors to minimize complications due to the disease.

\section{METHODS}

This research is a type of observational analytic research using a case control with a quantitative approach. This design can be used to assess the influence of risk factors in disease incidence (Sastroasmoro, 2011). The study was conducted at the Lampung DKT Hospital in April and July 2020 which analyzed the influence of risk factors related to the incidence of outpatient type 2 diabetes, where the researcher identified the case group with the control group then examined retrospectively on the risk factors

The population in this study were all outpatients at the Internal Medicine Department at DKT Hospital during the study. The sample in the case group, outpatient type 2 diabetes mellitus at DKT Hospital in Lampung, was based on the diagnosis of the Clinical doctor at the Internal Medicine Department at DKT Hospital Lampung. The sample in the control group, outpatients at the Internal Medicine Department of the DKT Hospital, Bandar Lampung, was diagnosed to other diagnosis without having type 2 diabetes mellitus. The sampling technique used purposive sampling. In this sampling technique, the researcher chooses respondents based on subjective considerations / characteristics / special and practical characteristics and it is hoped that these respondents can provide adequate information to answer research questions (Hidayat, 2017)

Inclusion criteria were cases of outpatients with type 2 diabetes whose diagnosis was made by a doctor, willing to be interviewed, aged 18 years to $\leq 65$ years. In control respondents, outpatients at the Internal Medicine Department of the DKT Hospital in Bandar Lampung who were diagnosed as not type 2 diabetes mellitus, patients who were willing to be interviewed and aged 18 years to $\leq 65$ years. While the exclusion criteria for cases and controls were outpatient type DM patients with unfavorable general conditions and / or suffering from psychotic disorders and / or having communication problems

Using gender for matching to minimize bias. The minimum sample size used in this case control study is a formula that uses the Odd Ratio (OR) as a measure of association (Lemeshow, 1991) using the value of the control proportion (p2) and OR (odd ratio) derived from previous studies. The data comes from interviews using a questionnaire guide conducted with respondents and PKRS officers at DKT Bandar Lampung Hospital and medical records. Interviews were conducted about risk factors for type 2 diabetes in case and control respondents by first giving informed consent and carrying out health protocols on covid 19 pandemic. Researchers applied health protocols at the time of 
data collection while maintaining a minimum distance of 1 meter from respondents, using masks and washing hands with soap.

Univariate analysis was used to explain the characteristics of each variable. Bivariate analysis to determine the relationship / influence between the independent variable and the dependent variable using the Chi-Square test with a confidence level of $95 \%$. Multivariate analysis to see the effect of several independent variables together on the type $2 \mathrm{DM}$ incidence variable so that it is known that the independent variable has the most dominant influence on the incidence of Type 2 DM by using multiple logistic regression (logistic binary regression).

\section{RESULTS}

A. Respondent Characteristics

Tabel 1. Frequency distribution of respondents based on characteristic in the DKT Hospital Bandar Lampung

\begin{tabular}{|c|c|c|c|c|c|c|}
\hline \multirow[t]{2}{*}{ Characteristic } & \multicolumn{3}{|c|}{ Case } & \multirow{2}{*}{$\frac{\text { Control }}{\%}$} & \multicolumn{2}{|c|}{ Total } \\
\hline & $\overline{\mathrm{N}}$ & $\%$ & $\mathrm{~N}$ & & $\mathrm{n}$ & $\%$ \\
\hline \multicolumn{7}{|l|}{ Gender } \\
\hline Male & 24 & 54,5 & 24 & 54,5 & 48 & 54,5 \\
\hline Female & 20 & 45,5 & 20 & 45,5 & 40 & 45,5 \\
\hline \multicolumn{7}{|l|}{ Age } \\
\hline$\geq 45$ year & 40 & 90 & 30 & 68,2 & 70 & 79,5 \\
\hline$<45$ year & 4 & 10 & 14 & 31,8 & 18 & 20,5 \\
\hline \multicolumn{7}{|l|}{ Education } \\
\hline High & 34 & 77,3 & 35 & 79,5 & 69 & 78,4 \\
\hline Low & 10 & 22,7 & 9 & 20,5 & 19 & 21,6 \\
\hline \multicolumn{7}{|l|}{ Occupation } \\
\hline Yes & 27 & 61,4 & 26 & 59 & 53 & 60,2 \\
\hline No & 17 & 38,6 & 18 & 41 & 35 & 39,8 \\
\hline
\end{tabular}

In this study, the number of respondents were 88 outpatients for Internal Medicine at the DKT Bandar Lampung Hospital, 44 case respondents and 44 control respondents. Of those who suffer from type 2 diabetes mellitus, there are 54.5\% male respondents. Meanwhile, in the group that did not suffer from type 2 diabetes mellitus, $54.5 \%$ were male. Of those who suffer from type 2 diabetes mellitus, there are as many as $90 \%$ of respondents aged $\geq 45$ years. Meanwhile, in the group that did not suffer from type 2 diabetes mellitus, there were $68.2 \%$ of respondents aged $\geq 45$ years. Of those who suffer from type 2 diabetes mellitus, there are $77.3 \%$ of respondents with higher education. Meanwhile, in the group that did not suffer from type 2 diabetes mellitus, there were $79.5 \%$ of respondents with higher education. Of those who suffer from type 2 diabetes mellitus, there are as many as $61.4 \%$ of respondents who work. Whereas in the group that did not suffer from type $2 \mathrm{DM}$, there were $59 \%$ of respondents who did not work

Tabel 2. Association between Age and Incidence of type 2 DM in outpatients at the DKT Bandar Lampung Hospital in 2020

\begin{tabular}{|c|c|c|c|c|c|c|c|c|}
\hline \multirow{3}{*}{ Age } & \multicolumn{4}{|c|}{ Type 2 DM } & \multirow{2}{*}{\multicolumn{2}{|c|}{ Total }} & \multirow{3}{*}{$P$ value } & \multirow{3}{*}{$\begin{array}{c}\text { OR } \\
\text { CI : } 95 \%\end{array}$} \\
\hline & \multicolumn{2}{|c|}{ Case } & \multicolumn{2}{|c|}{ Control } & & & & \\
\hline & $\mathrm{N}$ & $\%$ & $\mathrm{~N}$ & $\%$ & $\mathrm{~N}$ & $\%$ & & \\
\hline Risky & 40 & 90,9 & 30 & 68,2 & 70 & 79,5 & & 4,667 \\
\hline Non-Risky & 4 & 9,1 & 14 & 31,8 & 18 & 20,5 & 0,017 & $(1,395-15,616)$ \\
\hline Total & 44 & 100 & 44 & 100 & 88 & 100 & & \\
\hline
\end{tabular}

The table above shows that of the 44 case respondents (type 2 diabetes mellitus) there were 40 (90.9\%) with a risky age ( $\geq 45$ years) and of the 44 control respondents (not type 2 diabetes) there were $14(31.8 \%)$ respondents with non-risk age ( $<45$ years). Chi-square test results obtained $\mathrm{p}$ value $=0.017<0.05$. This means that there is a significant relationship / influence between age and the incidence of type 2 diabetes mellitus at the DKT Bandar Lampung Hospital in 2020. The OR $=4,667$ 
$(1,395-15,616)$ which indicates that patients with risky age ( $\geq 45$ years) are more at risk of experiencing type diabetes mellitus. 2 compared with patients of no risk age ( $<45$ years).

The table below shows that of the 44 case respondents (type 2 diabetes mellitus) there were $28(63.6 \%)$ with a history of heredity at risk (there was a genetic history of DM) and of 44 control respondents (not type $2 \mathrm{DM}$ ) there were $31(70,5 \%)$ of respondents with a history of non-risk descent (no history of heredity). Chi-square test results obtained $\mathrm{p}$ value $=0.003<0.05$. This means that there is a significant association between hereditary history and the incidence of type 2 diabetes mellitus at the DKT Bandar Lampung Hospital in 2020. OR $=4.173(1,709-10,188)$ which indicates that patients with a history of hereditary at risk (there is a genetic history of DM) are more at risk of experiencing diabetes. type 2 compared with patients with a non-risk inherited history (no hereditary history).

Tabel 3. Association between Hereditary history and Incidence of type 2 DM in outpatients at the DKT Bandar Lampung Hospital in 2020

Type 2 DM

\begin{tabular}{|c|c|c|c|c|c|c|c|c|}
\hline \multirow{2}{*}{$\begin{array}{l}\text { Hereditary } \\
\text { History }\end{array}$} & \multicolumn{3}{|c|}{ Case } & Control & \multicolumn{2}{|c|}{ Total } & \multirow[t]{2}{*}{$P$ value } & \multirow{2}{*}{$\begin{array}{l}\text { OR } \\
\text { CI : } 95 \%\end{array}$} \\
\hline & $\mathrm{n}$ & $\%$ & $\mathrm{n}$ & $\%$ & $\mathrm{~N}$ & $\%$ & & \\
\hline Risky & 28 & 63,6 & 13 & 29,5 & 41 & 46,6 & & 4,173 \\
\hline Non Risky & 16 & 36,4 & 31 & 70,5 & 47 & 53,4 & 0,003 & $(1,709-10,188)$ \\
\hline Total & 44 & 100 & 44 & 100 & 88 & 100 & & \\
\hline
\end{tabular}

Tabel 4. Association between history of the hypertension and incidence of type $2 \mathrm{DM}$ in outpatients at the DKT Bandar Lampung Hospital in 2020

Type $2 \mathrm{DM}$

\begin{tabular}{|c|c|c|c|c|c|c|c|c|}
\hline \multirow{2}{*}{$\begin{array}{l}\text { Hypertension } \\
\text { History }\end{array}$} & \multicolumn{2}{|c|}{ Case } & \multicolumn{2}{|c|}{ Control } & \multicolumn{2}{|c|}{ Total } & \multirow[t]{2}{*}{$P$ value } & \multirow{2}{*}{$\begin{array}{l}\text { OR } \\
\text { CI : } 95 \%\end{array}$} \\
\hline & $\mathrm{n}$ & $\%$ & $\mathrm{n}$ & $\%$ & $\mathrm{~N}$ & $\%$ & & \\
\hline Risky & 27 & 61,4 & 19 & 43,2 & 46 & 52,3 & & 2,090 \\
\hline Non Risky & 17 & 38,6 & 25 & 56,8 & 42 & 47,7 & 0,135 & $(0,892-4,894)$ \\
\hline Total & 44 & 100 & 44 & 100 & 88 & 100 & & \\
\hline
\end{tabular}

The table above shows that of the 44 case respondents (type 2 diabetes mellitus) there were 27 (61.4\%) with a history of risky hypertension (there was a history of hypertension) and of 44 control respondents (not type 2 diabetes) there were $25(56,8 \%)$ respondents do not have a history of hypertension. Chi-square test results obtained $\mathrm{p}$ value $=0.135<0.05$. This means that there is no significant relationship / influence between the history of hypertension and the incidence of type 2 diabetes mellitus at the DKT Bandar Lampung Hospital in 2020.

Tabel 5. Association between physical activity and incidence of outpatient type 2 diabetes mellitus at the DKT Bandar Lampung Hospital 2020

Type $2 \mathrm{DM}$

\begin{tabular}{|c|c|c|c|c|c|c|c|c|}
\hline \multirow[b]{2}{*}{ Physical Activity } & \multicolumn{2}{|c|}{ Case } & \multicolumn{2}{|c|}{ Control } & \multicolumn{2}{|c|}{ Total } & \multirow[t]{2}{*}{$P$ value } & \multirow{2}{*}{$\begin{array}{l}\text { OR } \\
\text { CI : } 95 \%\end{array}$} \\
\hline & $\mathrm{N}$ & $\%$ & $\mathrm{n}$ & $\%$ & $\mathrm{~N}$ & $\%$ & & \\
\hline Risky & 36 & 81,8 & 21 & 47,7 & 57 & 64,8 & & 4,929 \\
\hline Non Risky & 8 & 18,2 & 23 & 52,3 & 31 & 35,2 & 0,002 & $(1,872-12,974)$ \\
\hline Total & 44 & 100 & 44 & 100 & 88 & 100 & & \\
\hline
\end{tabular}

The table above shows that of the 44 case respondents (type 2 diabetes mellitus) there were 36 $(81.8 \%)$ with risky physical activity (low physical activity) and of the 44 control respondents (not type $2 \mathrm{DM}$ ) there were $23(52,3 \%)$ respondents with physical activities that are not at risk (moderate / high physical activity). Chi-square test results obtained $\mathrm{p}$ value $=0.002<0.05$. This means that there is a significant relationship / influence between physical activity and the incidence of type 2 diabetes mellitus at the DKT Bandar Lampung Hospital in 2020. The OR = 4,929 $(1,872-12,974)$ which indicates that patients with risky physical activity (low physical activity) are more at risk of experiencing the incident. Type 2 diabetes mellitus was compared with patients with physical activity that was not at risk (moderate or high activity). 
Tabel 6. Relationship between obesity and type 2 diabetes mellitus in outpatients at DKT Bandar Lampung Hospital in 2020

\begin{tabular}{|c|c|c|c|c|c|c|c|c|}
\hline \multirow[b]{2}{*}{ Obesity } & \multicolumn{2}{|c|}{ Case } & \multicolumn{2}{|c|}{ Control } & \multicolumn{2}{|c|}{ Total } & \multirow[t]{2}{*}{$\mathrm{P}$ value } & \multirow{2}{*}{$\begin{array}{l}\text { OR } \\
\text { CI : } 95 \%\end{array}$} \\
\hline & $\mathrm{n}$ & $\%$ & $\mathrm{n}$ & $\%$ & $\mathrm{~N}$ & $\%$ & & \\
\hline Risky & 32 & 72,7 & 16 & 36,4 & 48 & 54,5 & & 4,667 \\
\hline Non Risky & 12 & 27,3 & 28 & 63,6 & 40 & 45,5 & 0,001 & $(1,890-11,526)$ \\
\hline Total & 44 & 100 & 44 & 100 & 88 & 100 & & \\
\hline
\end{tabular}

The table above shows that of the 44 case respondents (type 2 diabetes mellitus) there were 32 $(72.7 \%)$ with obesity at risk (BMI $\geq 25$ ) and of 44 control respondents (not type 2 diabetes) there were $28(63.6 \%)$ obese respondents who are not at risk (BMI <25). Chi-square test results obtained p value $=0.001<0.05$. This means that there is a significant relationship / influence between obesity and the incidence of type 2 diabetes mellitus at the DKT Bandar Lampung Hospital in 2020. The OR $=4.66$ $(1,890-11,526)$ which indicates that patients with obesity are at risk $(\mathrm{BMI} \geq 25)$ more at risk 4, 66 times the incidence of type 2 diabetes was compared with obese patients who were not at risk (BMI $<25)$.

Tabel 7. The final model of multivariate analysis

\begin{tabular}{lllll}
\hline Variabel & Sig. & $\operatorname{Exp}(\mathrm{B})$ & \multicolumn{2}{c}{ CI 95\% for $\operatorname{Exp}(\mathrm{B})$} \\
\cline { 4 - 5 } & & & Lower & Upper \\
\hline Age & 0,047 & 4,552 & 1.023 & 20,254 \\
\hline Physical Activity & 0,006 & 5,291 & 1,618 & 17,308 \\
\hline Obesity & 0,005 & 5,139 & 1,639 & 16,109
\end{tabular}

From analysis processes that have been carried out, Among 5 independent variables that are suspected to be risk factors for the incidence of type 2 diabetes mellitus, there are 3 variables that are significantly associated with the incidence of type 2 diabetes, namely physical activity, age and obesity. Multivariate analysis shows that physical activity is the most dominant factor associated with the incidence of outpatient type 2 diabetes at the DKT Hospital Bandar Lampung in 2020 (p value 0.006 and OR 5.291) where respondents with low physical activity are at risk / have 5 times chance of having the incident Type 2 diabetes mellitus compared to respondents with non-risk physical activity.

\section{DISCUSSION}

In this study, there was an effect of age on the incidence of type 2 diabetes in outpatients at DKT Hospital Bandar Lampung. This is in line with Dafriani's research (2017) where the proportion of respondents who are not Type II Diabetes Mellitus is mostly found in respondents whose age category is not at risk compared to respondents who are at risk age category. The results of statistical tests obtained $p$ value 0.031 OR 4.32 , which means that there is a significant relationship between age and the incidence of type 2 Diabetes Mellitus.

In the elderly there is a decline in glucose tolerance, increased insulin resistance, reduced muscle mass and replaced by fat tissue resulting in a decrease in glucose uptake by muscle tissue. In the elderly, there is a decrease in mitochondrial function which causes the emergence of insulin resistance when compared to younger ages (Durruty, 2018). For elderly people with normal body mass index, there are more disturbances in insulin secretion in pancreatic beta cells, while for elderly people with obesity, there is more interference with insulin resistance in peripheral tissues such as muscle, liver cells, and fat cells (Waspadji, 2011). The risk of developing type II diabetes mellitus increases with age because the productive $\beta$ cells of the pancreas decrease with age, especially after 45 years of age. The aging process causes changes in fat metabolism. By increasing age, the composition of the fat in the human body is increasing and if it is excessive, for example, obese people tend to accumulate in the abdominal area and cause central obesity (Suastika, 2012).

In the aging process, the release of Free Fatty Acid (FFA) from fat tissue into the blood is more than at a young age and the sensitivity of fat tissue to the anti-lipolytic effect of insulin is also reduced so that the release of FFA in the blood increases which stimulates gluconeogenesis in the 
liver. FFA in the liver will stimulate the formation of VLDL (very low density lipoprotein) which plays a major role in atherogenic dyslipidemia disorders. There is a relationship between diabetes mellitus and changes in lipid profiles in the form of increased cholesterol, triglycerides and LDL in hypertensive patients aged 45-60 years (Fitriana, 2018).

From this study, it was found that $9.1 \%$ of case respondents aged $<45$ years were diagnosed with type 2 diabetes.Based on interviews by researchers, it was found that these respondents came to a health facility before being diagnosed with DM with classic symptoms of DM, namely lots of eating, lots of drinking and lots of waste Urine especially at night and the body gets tired easily. Respondents also have other risk factors besides diabetes, namely obesity, physical activity because they feel the body is too heavy to move swiftly and those who are not obese have a family history of both parents. Early detection in patients aged $<45$ years is recommended if they have risk factors such as obesity / overweight with one or more risk factors for DM and classic symptoms of DM.

There is an effect of hereditary history with the incidence of outpatient type 2 diabetes at the DKT Bandar Lampung Hospital. In line with Paramita.P et al (2019) with their research entitled "The effect of first family history on blood levels of type 2 diabetes mellitus sufferers at Puskesmas II Denpasar Selatan". The results showed that family history gave the offspring a greater risk of suffering from type 2 diabetes ( $p$ value 0.001 and OR 6.27). This research is in line with Sukmaningsih (2016), who states that there is a relationship between hereditary history and the incidence of type $2 \mathrm{DM}$ in the Purwodiningratan Surakarta Health Center with a $\mathrm{p}$ Value of 0.006 with an OR of 3.23 so that someone who has a history of DM in the family is at risk of 3 times for experienced type 2 diabetes mellitus.

The same study by Kekenusa, et al. (2013) This study shows that there is a relationship between family history of suffering from DM with the incidence of Type 2 diabetes with a $p$ value of 0.000 and an OR of 4.7. This means that people who have a family history of suffering from diabetes are at 5 times greater risk of developing Type 2 diabetes compared with people who do not have a family history of suffering from diabetes at the Internal Medicine Polyclinic, Prof. Dr. Dr. R. D. Kandou Manado.

The existence of genetic mutations and gene polymorphisms in certain enzymes and protein factors that are associated with insulin action signals to effector cells and insulin secretion can partly explain why genetics can impact type 2 diabetes (Durruty, 2018). Not everyone with this gene mutation will definitely get DM but people who have DM have one or more of these mutated genes. Some of the genes that have this mutation can interact with environmental factors and synergize with each other to increase risk factors for type 2 diabetes, including the involvement of one of the DM risk factors, namely obesity which can be passed on from parents.

From interviews with case respondents, it is illustrated that there is an interaction between hereditary history, environment and lifestyle. Some case respondents said that in addition to heredity, there were other triggers that caused them to develop DM. Respondents compared themselves with their siblings or siblings who were not affected by DM even though they both had a history of DM from their parents and were both older than 45 years. A sedentary lifestyle, a hobby of fried food, likes to sauté curry spices with oil, eat sweet foods, prefer to use a motorized vehicle when traveling short distances, for example to go to a shop near the house, are things that might accelerate the emergence of type 2 diabetes in people with a hereditary history of type $2 \mathrm{DM}$

There are $29.5 \%$ of respondents who do not suffer from type 2 diabetes but have a risk of hereditary DM. This means that control respondents are also at risk of suffering from diabetes at a later age, especially if there are other factors that will trigger it because type 2 diabetes occurs due to interactions between genetic, genetic changes and environmental factors (ADA Care, 2019).

There is no effect of hypertension history with the incidence of outpatient type 2 DM at DKT Hospital Bandar Lampung. The results of this study are in line with Sun D et al (2019) in their study of Type 2 diabetes and hypertension, a study of bidirectional causality which suggests there is no relationship between hypertension and type 2 diabetes with $\mathrm{p}$ value 0.35 and OR 0.96 . Research conducted by Trisnawati (2012) also stated that hypertension was not proven to increase risk factors for type 2 diabetes in her research at the South Denpasar Health Center.

The two studies contradict the results of the research by Rofikoh.dkk (2020) which states that people with a history of hypertension are three times more likely to suffer from type 2 diabetes in the study The determinant of Diabetes mellitus type 2 in Posbindu Mawar Kuning with a $p$ value of 0.004. This study is also in line with Kabosu et al. (2019) which explains that there is a significant relationship with the incidence of type 2 diabetes $\mathrm{p}$ value 0.0019 where respondents who have a history of hypertension are at 3.42 times greater risk than respondents who do not have a history of hypertension. 
In a journal entitled "Hypertension is an independent risk factor for type 2 DM" Kim (2015) explains that there is a significant relationship between hypertension and the emergence of diabetes mellitus in the future with the Cohort study design. In a prospective study that was followed for 8 years, $21.8 \%$ of hypertensive patients suffered from DM after controlling for confounding factors with RR 1.51.

Lastra et.al (2013) DM and hypertension have almost similar pathophysiology including poor activation of the renin angiotensin aldosterone system (RAAS), oxidative stress due to overproduction of reactive oxygen species (ROS / Reactive Oxygen Species), chronic inflammation, increased activation sympathetic nervous system, dysfunctional immune response and abnormal sodium absorption in the kidneys. Obesity and accumulation of adipose tissue / visceral fat are key pathogens of coexisting DM and hypertension. Adipose tissue is known to produce adipokines which can stimulate aldosterone production from the adrenal gland's glomerulose zone. Activation of aldosterone at mineral-corticoid receptors in the distal tubule and renal collecting duct causes sodium retention and causes an increase in blood plasma volume which is responsible for the increase in blood pressure. Conversely, hypertension can lead to microvascular dysfunction. Hypertension also causes endothelial dysfunction in blood vessel walls which is associated with insulin resistance and contributes to the natural history of DM.

The results showed that $43.2 \%$ of control respondents with a history of hypertension did not have type 2 diabetes (control). From interviews with control respondents who had suffered from hypertension, most of the respondents were already and obedient to taking antihypertensive drugs and for various reasons such as wanting to relieve symptoms of sore neck due to increased blood pressure or case respondents were afraid of complications of hypertension, namely stroke.

In line with Nurmalita's research (2019) where there is a significant relationship between adherence to taking antihypertensive drugs on the quality of life of hypertensive patients with $\mathrm{p}$ $<0.001$. Some of them have also reduced salt in their daily diet. This is in line with the research of Azmardina (2012) in her study. The relationship between excessive salt consumption and hypertension is uncontrolled in hypertensive patients. In this study, it was found that there was a significant relationship between excess salt consumption and uncontrolled hypertension in patients aged at least 20 years at the Puskesmas, Srengseng Village. Respondents who consumed excess salt had a 1.71 times greater risk (OR 1.71) of suffering from uncontrolled hypertension compared to respondents who consumed moderate salt. This is what might cause control respondents to avoid the emergence of type $2 \mathrm{DM}$.

This discussion shows the importance of prevention, management and treatment of risk factors for hypertension before the emergence of Diabetes mellitus. There is the effect of low physical activity on the incidence of outpatient type 2 DM at DKT Hospital in 202 which was obtained in this study. Sukmaningsih (2016) states the same opinion that there is a significant relationship between physical activity and the incidence of type 2 diabetes with a p value of 0,000 and OR 7,737 which means that the incidence of type 2 diabetes has an 8 times higher risk of occurring in someone who has low physical activity. Research conducted by Aravinda (2019) states the same thing, namely there is a relationship between low physical activity and the incidence of type 2 diabetes mellitus in Bangalore, India with a $p$ value of 0.0001 .

Physical activity reduces fasting blood glucose and glycolated hemoglobin ( $\mathrm{HbAlc}$ ), improves lipid profile, improves decreasing blood pressure, reduces inflammation and oxidative stress and improves quality of life. Physical activity increases the uptake of blood glucose by cells, so that this activity can control blood sugar.

From the results of interviews with patients with type 2 diabetes mellitus, some of the case respondents who suffered from type 2 diabetes said that after the respondent was more than 45 years old, even though they ate the same amount before being fat, the respondent's weight continued to increase. Because of the weight gain, respondents feel more lazy to move, prefer to work while sitting and do not exercise because they feel tired and sweaty if they do activities with fast movements.

There is a synergy between weight gain, inadequate physical activity and increasing age which allows respondents to be more susceptible to type 2 diabetes. In this study it can be seen that low physical activity is not only a risk factor for type 2 diabetes. $47.7 \%$ of control respondents who have low physical activity but do not suffer from type 2 diabetes. This means that the respondent is at risk of developing DM with increasing age if there are other risk factors that the respondent has. From the ADA Care Journal (2019) by taking action through lifestyle improvements such as diligent physical activity according to WHO recommendations, losing weight and regulating diet and the number of calories can prevent the incidence of type 2 diabetes by $58 \%$

The results of this study, there is an effect between obesity and the incidence of type 2 diabetes outpatients in RS DKT Bandar Lampung. In line with Handayani's research, T et al (2018) at 
Puskesmas Olak Kemang Jambi that there is a relationship between obesity and the incidence of type 2 diabetes, the results of bivariate analysis show that obesity has a significant relationship with the incidence of type 2 diabetes with p value 0.001 and OR 4.529. This research is supported by research conducted by Sari (2018) which suggests that there is a significant relationship between central obesity and the incidence of Type 2 Diabetes Mellitus.

Nasution et al (2018) suggest that in obese people, the pancreas actually still produces sufficient amounts of insulin so that blood glucose can be maintained at normal conditions. However, the insulin then loses its ability to carry out its function so that it does not work effectively on target cells and is unable to help glucose absorption blood by cells. If it lasts long, the pancreas will then lose the ability to produce insulin. The condition in which insulin cannot work effectively and the amount of insulin secretion is reduced will become insulin resistance (Setiati, 2014).

Obesity is one of the factors that play a role in the incidence of type 2 diabetes through the insulin resistance mechanism. There are 2 mechanisms linking obesity to the incidence of type 2 diabetes, namely increased production of cytokines including tumor necrosis factor, resistin and retinol-binding protein4 and through mitochondrial dysfunction. Increased cytokinins and mitochondrial dysfunction contribute to insulin resistance and may increase blood glucose levels Bournat (2010)

In people with obesity there is leptin resistance, where there is an increase in leptin levels in blood plasma but leptin does not function normally (Oussada, 2019). This inhibits glucose uptake, resulting in an increase in blood sugar levels. In this study, there were $36.4 \%$ of control respondents who had a risk of obesity but did not suffer from type 2 diabetes. There were other factors besides obesity that might trigger cases. Prevention of diabetes that is triggered by obesity is by intervening in lifestyle, one of which is by maintaining weight loss of $7 \%$ and doing moderate physical activity, for example walking fast for at least 150 minutes per week on a regular basis where physical activity helps uptake glucose into the muscles so that glucose levels in the blood can decrease and improve diet. This combination can reduce the probability of developing diabetes by $58 \%$ in 3 years (ADA Care, 2019).

Multivariate analysis shows that physical activity is the most dominant factor associated with the incidence of outpatient type 2 diabetes at the DKT Hospital Bandar Lampung in 2020. People with low physical activity or living with a sedentary pattern / physical inactivity have an increased risk of $20 \%-30 \%$ experiencing death compared to people with sufficient physical activity (WHO, 2017).

Physical activity, including physical exercise, are all body movements produced by skeletal muscles and require energy (Soofie $\mathrm{N}$ et al., 2015). Physical exercise is physical activity that is structured and planned. Physical activity, either daily physical activity or physical exercise, can improve cardiorespiratory function, increase glycemic control, decrease insulin resistance, lower blood pressure and maintain weight loss. This type of physical exercise consists of aerobic exercise, resistance training and flexibility training. Aerobic exercise involves rhythmic and sustained movement of large muscles. Resistance training is repetitive physical exercise using weights. Flexibility exercises aim to increase the ability to move as far as the range of motion of the joint. Doing moderate physical activity on a regular basis reduced the chances of developing type 2 diabetes by $58 \%$ in 2.8 years. (Hamasaki $\mathrm{H}, 2016$ ).

Some of the patients interviewed in this study said that their physical movements were not as strong as their friends who were the same age and did not suffer from DM. Patients under 55 years of age also complain of being easily weak and tired if they have to do movements such as aerobics or lifting weights and must be done at least 30 minutes a day.

Obese type $2 \mathrm{DM}$ patients also claim to have difficulty moving swiftly because of their large bodies. Other patients also said they were already busy with daily activities so they felt they had "enough" to move and no longer needed to exercise. The fact is that patients with type $2 \mathrm{DM}$ tend to have weaker muscle strength than those who do not suffer and it is inversely related to the degree of diabetes complications where the more organ complications due to diabetes the less muscle strength they have (Balducci, 2010).

Therefore it is advisable to keep doing daily activities as usual according to ability, stopping the sedentary lifestyle (working while sitting or relaxing while sitting for a long time) by doing light activities every 30 minutes such as walking and light body movements and physical exercise according to WHO recommendations 3 times a week, 150 minutes a week of moderate or high physical activity if you can

Patients are also advised to adjust physical activity with the DM complications they suffer. The ability of self-management in patients in the form of the ability to control and reduce the impact of DM disease on them is expected to always be obtained from the education program of the PKRS (Hospital Health Promotion) of the DKT Hospital in Bandar Lampung. 
Because age is an irreversible risk factor for type 2 diabetes, the possibility of other risk factors must be identified and addressed immediately. Weight loss of at least $5 \%$ in obese patients because it can normalize blood pressure, improve glycemic control and lipid profile. In accordance with the 5 pillars of DM management from Perkeni (2015), namely education, physical activity, eating arrangements, use of diabetes drugs as recommended and monitoring blood sugar, it is hoped that patients with type 2 diabetes can live a normal and productive life

\section{CONCLUSION}

The frequency distribution of the case group of patients with outpatient type 2 diabetes at DKT Hospital based on age at risk was $90.9 \%$, hereditary history of DM at risk was $63.6 \%$, history of hypertension at risk was $61.4 \%$, physical activity at risk was $81,8 \%$ and obesity at risk of $72.7 \%$. There is a significant influence between the risk factors for age, Hereditary history, obesity, physical activity and the incidence of type 2 diabetes mellitus at the DKT Bandar Lampung Hospital in 2020. There was no significant effect between a history of hypertension and the incidence of type 2 diabetes mellitus at the DKT Bandarlampung Hospital in 2020. And Physical activity is the most dominant factor that influences the incidence of type 2 diabetes mellitus at the DKT Bandar Lampung Hospital in 2020 .

\section{SUGGESTION}

Early detection in patients who have risk factors for type 2 diabetes even though they come to the hospital with another diagnosis. Prompt management of risk factors for type 2 diabetes melittus so that can be prevented as soon as possible. Strenghtening competency of the Hospital Health Promotion Officers to give education and empowering patients to change behaviors and lifestyles about risk factors for type 2 diabetes and how to prevent and overcoming them. To make the type 2 DM patients understand how to cope with acute and chronic complications, independent monitoring of body weight and blood sugar as well as a healthy lifestyle and prevention of long-term complications such as providing counseling to increase knowledge, motivation in physical activity and consultation on nutritional knowledge in dietary regulation and take medication regularly so that sugar levels are more controlled for sufferers of type 2 DM. It is hoped that this research can be used as input and comparison for further research. As well as considering other variables to be studied using other methods with a better level of validity.

\section{REFERENCE}

American Diabetes Association(ADA). Standart of medical Care Update 2019. Retrieved from https://care.diabetesjournals.org/content/ pada tanggal 4 Februari 2020

Atzmardina Z. 2012. Hubungan antara konsumsi garam berlebih dengan hipertensi tidak terkendali pada pasien hipertensi. Di akses di https://journal.untar.ac.id/index.php/ebers_papyrus/article/view/645 pada tanggal 15 Juli 2020.

Balducci S, et al.2010. Effect of an intensive exercise intervention strategy on modifiable cardiovascular risk factors in subjects with type 2 diabetes mellitus: a randomized controlled trial: the Italian Diabetes and Exercise Study (IDES). Diakses di https://pubmed.ncbi.nlm.nih.gov/21059972/ pada tanggal 2 Juli 2020.

Bournat. JC, Brown CW. 2010. Mitochondrial dysfunction in obesity. Curr Opin Endocrinal diabetes Obes 2010; 17:446-452

Dafriani P, 2017. Hubungan obesitas dan umur pada penderita DM tipe 2. e-ISSN : 2540-961 p-ISSN : 2087-8508diakses di http://jurnal.syedzasaintika.ac.id/index.php/medika/article/view/95/0 tanggal 1 Februari 2020.

Durruty P. 2019. Pathogenesis of Type 2 Diabetes Mellitus. Diakses di https://www.researchgate.net/publication/331016768_Pathogenesis_of_Type_2_Diabetes_Me llitus pada tanggal 2 Juli 2020

Fitriana I. 2018. Hubungan diabetes melitus dengan profil lipid pada penderita hipertensi umur 45-60 tahun. Diakses di http://www.repository.trisakti.ac.id/webopac_usaktiana/index.php/home/detail/pada tanggal 2 Juli 2020

Hamasaki, H. 2016. Daily physical activity and type 2 diabetes: A review. doi: 10.4239/wjd.v7.i12.243 Diakses https://www.ncbi.nlm.nih.gov/pmc/articles/PMC4914832/\#B34 pada tanggal 27 Februari 2020 
Handayani, T et all. 2018. Hubungan obesitas dan aktifitas fisik dengan kejadian DM tipe 2 di Puskesmas Olak Kemang Jambi terdapat hubungan antara obesitas dengan kejadian DM tipe

2. Diakses di https://online-journal.unja.ac.id/jkmj/article/view/6535 pada tanggal 2 Juli 2020

Hariawan H,dkk. 2019. Hubungan pola makan dengan aktifitas fisik pada pasien DM tipe 2 di RSU

Provinsi NTB. Diakses di

https://www.researchgate.net/publication/336895418_Hubungan_Gaya_Hidup_Pola_Makan_ dan_Aktivitas_Fisik_Dengan_Kejadian_Diabetes_Melitus_di_Rumah_Sakit_Umum_Provinsi _NTB pada tanggal 15 Juli 2020

Hidayat, A.2017. Penjelasan teknik purposive sampling detail. Diakses di https://www.statistikian.com/2017/06/penjelasan-teknik-purposive-sampling.html pada tanggal 15 Feb 2020

Idf.org. The global impact of diabetes. Diakses dari https://idf.org/ akses pada tanggal 19 Februari 2020

Kekenusa. S et al. 2013. Analisis hubungan antara umur dan riwayat keluarga menderita DM dengan kejadian penyakit DM tipe 2 pada pasien rawat jalan di Poliklinik Penyakit Dalam BLU RSUP Prof Dr. R. D. Kandou Manado. Diakses di https://fkm.unsrat.ac.id/wpcontent/uploads/2013/08/GLORIA-WUWUNGAN-091511080.pdf pada tanggal 28 Juni 2020

Kabosu, S dkk. 2019. Faktor resiko kejadian DM tipe 2 di RS Bhayangkara Kota Kupang. Diakses di https://ojsfkmundana.science/index.php/t/notification pada tanggal 22 Februari 2020

Kesmas.kemkes,go.id. Hasil Riskesdas 2018 diakses di http://www.kesmas.kemkes.go.id/assets/upload/dir_519d41d8cd98f00/files/Hasil-riskesdas2018_1274.pdf pada tanggal 23 januari 2020

Lastra, G.et al. 2013. Type 2 diabetes mellitus and hypertension: An update. Diakses https://www.ncbi.nlm.nih.gov/pmc/articles/PMC3942662/ tanggal 1 Juli 2020

Lemeshow,S.,Et.al.1990.Adequacy of Sample size in health studies. Who:19 https://apps.who.int/iris/bitstream/handle/10665/41607/0471925179_eng.pdf;sequence=1 diakses tanggal 30 januari 2020

Litbang.kemkes.go.id.Beban Ganda penyakit mengancam Indonesia. 2019. Diakses di https://www.litbang.kemkes.go.id/beban-ganda-penyakit-mengancam-indonesia/ pada tanggal 13 Februari 2020

Nurmalita V. 2019. Hubungan kepatuhan minum obat antihipertensi terhadap kualitas hidup pasien hipertensi. Di akses di https://ejournal3.undip.ac.id/index.php/medico/article/view/25813 pada tanggal 23 Juni 2020

Oussadda, S. 2019. The pathogenesis of obesity. Diakses di https://www.sciencedirect.com/science/article/pii/S0026049519300071 pada tanggal 6 Juli 2020

Paramita. $\mathrm{P}$ et al. 2019. Pengaruh riwayat keluarga keturunan pertama terhadap kadar glukosa darah dari penderita DM tipe 2 di Puskesmas II Denpasar Selatan. Diakses di https://ojs.unud.ac.id/index.php/eum/article/download/50219/29890/ pada tanggal 6 Juni 2020

Perkeni. 2015. Konsensus Pengelolaan dan pencegahan DM tipe 2 di Indonesia.2015. Diakses di https://pbperkeni.or.id/wp-content/uploads/2019/01/4.-Konsensus-Pengelolaan-danPencegahan-Diabetes-melitus-tipe-2-di-Indonesia-PERKENI-2015.pdf pada tanggal 2 Februari 2020

Rofikoh dkk. 2020. The determinant of diabetes mellitus type 2 in Posbindu Mawar Kuning gambir. Arkesmas. Vol.5-1.Juni 2020:42

Sastroasmoro S., 2011. Dasar Dasar Metodologi Penelitian Klinis, Jakarta : Sagung Seto

Setiati S, Alwi I, Sudoyo A, Simadibrata M, Setyohadi B, Syam A. Buku Ajar Ilmu Penyakit Dalam. Ke-6 jilid. Jakarta Pusat: Interna Publishing (Pusat Penerbitan Ilmu Penyakit Dalam) Universitas Indonesia; 2014.

Soofie N, Detel. R. 2015. Oxford Public Health. Physical Activity and Health p.992

Suastika et.al, 2012. Age is an Important Risk Factor for Type 2 Diabetes Mellitus and Cardiovascular Diseases. DOI: 10.5772/52397. https://www.intechopen.com/books/glucose-tolerance/age-isan-important-risk-factor-for-type-2-diabetes-mellitus-and-cardiovascular-diseases diakses pada tanggal 3 Februari 2020

Sukmaningsih.R et al. 2016. Faktor Resiko kejadian DM tipe 2 di wilayah kerja Puskesmas Purwodiningratan Surakarta

Sun.X et al.2014. Genetics of Type 2 Diabetes: Insights into the Pathogenesis and Its Clinical Application. Diakses http://dx.doi.org/10.1155/2014/926713 tanggal 1 Juli 2020 
Sun.D et al. 2019. Type 2 diabetes and hypertension, a study of bidirectional causality. Diakses di https://www.ahajournals.org/doi/10.1161/CIRCRESAHA.118.314487 pada tanggal 1 Juli 2020.

Trisnawati, K \& Setyorogo, S, 2013. Faktor resiko kejadian diabetes tipe 2 di puskesmas kecamatan cengkareng jakarta barat.http://fmipa.umri.ac.id/wp-content/uploads/2016/06/YUNI-INDRIFAKTOR-RESIKO-DM.pdf diakses tanggal 30 Januari 2020

Waspadji, Sarwono. 2011. Diabetes Mellitus : Mekanisme Dasar dan Pengelolaannya yang rasional. Jakarta : Balai Penerbit FKUI.

WHO.2020. Diabetes. Key Facts. Diakses di https://www.who.int/news-room/factsheets/detail/diabetes pada tanggal 20 Juni 2020

WHO.2019. Classification of DM https://www.who.int/health-topics/diabetes diakses pada tanggal 4 februari 2200

WHO. 2013. Physical Activity diakses https://www.who.int/topics/physical_activity/en/ pada tanggal 6 Februari 2020

Wu Yanling, Et.all, 2014. Risk Factors Contributing to Type 2 Diabetes and Recent Advances in the Treatment and Prevention. Diakses di https://www.ncbi.nlm.nih.gov/pmc/articles/PMC4166864/ Risk pada tanggal 5 Februari 2020 